


\section{Historical atmospheric pollution trends in Southeast Asia inferred from lake}

\section{2 sediment records}

4 Engels $\mathrm{S}^{1,2^{*}}$, Fong $\mathrm{LSRZ}^{3}$, Chen $\mathrm{Q}^{3}$, Leng $\mathrm{MJ}^{1,4}$, McGowan $\mathrm{S}^{1,5}$, Idris $\mathrm{M}^{6}$, Rose $\mathrm{NL}^{7}$, Shafiq $\mathrm{M}^{6}$, Taylor $\mathrm{D}^{3}$,

5 Yang $\mathrm{H}^{7}$

6

7 Affiliations

$8{ }^{1}$ Centre for Environmental Geochemistry, School of Geography, University of Nottingham,

9 Nottingham, NG7 2RD, UK

$10{ }^{2}$ School of Geography, Birkbeck University of London, Malet Street, London, WC1E 7HX, UK

$11{ }^{3}$ Department of Geography, National University of Singapore, Singapore, 117570, Singapore

$12{ }^{4}$ NERC Isotope Geosciences Facilities, British Geological Survey, Nottingham, NG12 5GG, UK

$13{ }^{5}$ School of Environmental and Geographical Sciences, University of Nottingham-Malaysia Campus,

14 Jalan Broga, 43500 Semenyih, Selangor Darul Ehsan, Malaysia

$15{ }^{6}$ Tasik Chini Research Centre, Faculty of Science and Technology, Universiti Kebangsaan Malaysia,

16 43600, Malaysia

$17{ }^{7}$ Environmental Change Research Centre, Department of Geography, University College London,

18 London, WC1E 6BT, UK

19 *author for correspondence; s.engels@bbk.ac.uk 
Fossil fuel combustion leads to increased levels of air pollution, which negatively affects human health as well as the environment. Documented data for Southeast Asia (SEA) show a strong increase in fossil fuel consumption since 1980, but information on coal and oil combustion before 1980 is not widely available. Spheroidal carbonaceous particles (SCPs) and heavy metals, such as mercury $(\mathrm{Hg})$, are emitted as by-products of fossil fuel combustion and may accumulate in sediments following atmospheric fallout. Here we use sediment SCP and Hg records from several freshwater lentic ecosystems in SEA (Malaysia, Philippines, Singapore) to reconstruct long-term, region-wide variations in levels of these two key atmospheric pollution indicators. The age-depth models of Philippine sediment cores do not reach back far enough to date first SCP presence, but single SCP occurrences are first observed between 1925 and 1950 for a Malaysian site. Increasing SCP flux is observed at our sites from 1960 onward, although individual sites show minor differences in trends. SCP fluxes show a general decline after 2000 at each of our study sites. While the records show broadly similar temporal trends across SEA, absolute SCP fluxes differ between sites, with a record from Malaysia showing SCP fluxes that are two orders of magnitude lower than records from the Philippines. Similar trends in records from China and Japan represent the emergence of atmospheric pollution as a broadly-based inter-region environmental problem during the $20^{\text {th }}$ century. $\mathrm{Hg}$ fluxes were relatively stable from the second half of the $20^{\text {th }}$ century onward. As catchment soils are also contaminated with atmospheric $\mathrm{Hg}$, future soil erosion can be expected to lead to enhanced $\mathrm{Hg}$ flux into surface waters.

'Capsule' - Lake sediment records from Southeast Asia provide first data on historical trends in fossil-fuel derived atmospheric pollution

Keywords: fossil fuel combustion; emission trends; fly ash particles; mercury; Southeast Asia 


\section{Introduction}

Asia has undergone strong economic growth over the last few decades leading to a doubling in regional energy consumption between 1980 and 2003 (Richter et al., 2005; Ohara et al., 2007), with a continuous growth of energy consumption being observed since 2003 (Kurokawa et al., 2013; EANET, 2015). Fossil fuel combustion emits atmospheric pollutants, particularly $\mathrm{SO}_{2}, \mathrm{NO}_{x}, \mathrm{CO}$, nonmethane volatile organic compounds, organic carbon, black carbon and trace metals. Although pollutant emissions, particularly from the burning of coal, have been declining in Europe and North America over the last two decades, this has not been the case for much of Asia (Amann et al., 2013; Klimont et al., 2013; Kurokawa et al., 2013). While emissions of $\mathrm{SO}_{2}$ and particulate matter $\left(\mathrm{PM}_{2.5}\right)$ decreased by 12-15\% in East Asia between 2005 and 2010, emissions of $\mathrm{NO}_{\mathrm{x}}$ and non-methane volatile organic compounds increased by $15-25 \%$ (Wang et al., 2014). Electricity demand in Southeast Asia (SEA), one of the world's fastest developing regions, is projected to be $83 \%$ higher in 2035 than in 2011 (International Energy Agency, 2013), with coal providing much of this increased energy demand (Lai et al., 2016).

Increased atmospheric pollution has major implications for society and the environment. An estimated 6.5 million deaths globally each year are attributed to poor air quality (International Energy Agency, 2016; World Health Organization Press, 2016). Koplitz et al. (2017) suggest that the current estimate of around 20,000 (11.4-28.4 x 103) excess deaths per year due to emissions from burning coal in SEA will increase to around 70,000 (40.1-126.7 $\left.\times 10^{3}\right)$ by 2030. Perhaps contrary to common perception (Lai et al., 2016), around 9000 of these excess deaths as a result of increased coal use in SEA are anticipated to occur in China; rising coal emissions in SEA could thus become an increasingly transboundary pollution issue (Koplitz et al., 2017).

Atmospheric greenhouse gas concentrations resulting from fossil fuel combustion are one of the key drivers of anthropogenic climate change (IPCC, 2014), and aerosols (particularly atmospheric black carbon) can significantly influence global radiative forcings (Jacobson, 2001; Streets et al., 2004). Fine aerosol particles can further influence regional climate via surface dimming (Ramanathan et al., 2005; Lau et al., 2006); Fu et al., 2017). Atmospherically deposited pollution places further pressure on anthropogenically impacted wetlands and lowland lakes in SEA, with existing impacts including eutrophication, intensified aquaculture, water abstraction, dam construction, biomass burning, as well as catchment disturbances such as agriculture (e.g. oil palm and other plantations), urbanisation and mining activities (Sharip et al., 2014). Those aquatic ecosystems that have not been severely degraded yield valuable services, such as food and water for local populations and the provision of livelihood opportunities such as eco-tourism (Shuhaimi-Othman et al., 2007; Stockholm International Water Institute, 2009; Sharip and Jusoh, 2010). These services may be difficult to 
replace. Moreover, human impacted aquatic ecosystems are likely to have significantly reduced biodiversity value (Kopf et al., 2015). Unfortunately, information on the current status of many of these ecosystems, and on the rates and directions of change in environmental conditions over recent decades, is generally lacking. In addition, detailed inventories of anthropogenic energy sources and emissions for Asia only span the last few decades (Kato and Akimoto, 1992; Akimoto 2003; Streets et al., 2003; Kurokawa et al., 2013) and their number is comparatively low (Ohara et al., 2007; Rose 2015).

Natural archives such as lake sediments have the potential to provide essential information on spatio-temporal variations in fossil fuel consumption in SEA, as spheroidal carbonaceous particles (SCPs), by-products of high-temperature industrial fossil fuel combustion, can be stored in these sediment records following atmospheric deposition, thus tracking changing influx with time (Rose 2015). SCPs are fine carbonaceous aerosols, typically 2-50 $\mu \mathrm{m}$ across, formed from the incomplete high-temperature combustion of fossil fuels such as oil and coal (Rose et al., 1994; Rose 2001; Chirinos et al., 2006). SCPs can be transported for thousands of kilometres through the atmosphere under favourable meteorological conditions (Rose et al., 1998; Yang et al., 2001; Inoue et al., 2014), and have been found in remote places such as the Falkland Islands and Antarctica, far removed from the nearest sources (Rose et al., 2012). SCPs are a component of the "black carbon continuum" (Rose, 2008; 2015), but whereas other components of black carbon can be the result of domestic emissions, road transport emissions, or biomass burning (e.g. Kurokawa et al., 2013), SCPs are only formed during high-temperature industrial fossil fuel combustion. As they have no natural sources, SCPs encountered in lake sediment records can be used as indicators of atmospheric deposition from industrial sources (Rose, 2001), especially as they are not susceptible to post-depositional alteration, movement in the sediment column (except by bioturbation), or degradation (Rose et al., 2003). Analysis of SCPs stored in sediments provides a means to reconstruct trends in emissions from the combustion of fossil fuels over time-periods that extend beyond the beginning of documentary and instrumental evidence, which commenced only in the second half of the $20^{\text {th }}$ century and in some regions even more recently (Rose, 2001). Spatial patterns in SCP distribution have been shown to be closely linked to other pollutants, such as sulphur and polycyclic aromatic hydrocarbons (Rose and Juggins 1994; Rose et al., 1998; Barst et al., 2017). A global collation of SCP records includes a disproportionately large number of records from Western Europe and none from SEA (Rose, 2015).

Anthropogenic emissions of $\mathrm{Hg}$ date back to pre-industrial times, but global $\mathrm{Hg}$ emission rates have tripled over the last 150 years, mainly due to increased coal burning (Hylander and Meil, 2003; Engstrom et al., 2014; Horowitz et al., 2014; Yang et al., 2016). Aside from industrial sources, 
there are many additional anthropogenic sources of atmospheric $\mathrm{Hg}$ emission, including waste incineration, sulphide ore processing, cement kilns and the production of various metals (Hylander and Meil, 2003). Another important potential source of atmospheric $\mathrm{Hg}$ is artisanal and small-scale gold mining (Mason and Pirrone 2009, Cordy et al., 2010). Hg is among the most toxic elements and poses serious threats to both human health and aquatic ecosystems due to its tendency to bioaccumulate and biomagnify through the food chain (Azimi and Moghaddam, 2013; Rice et al., 2014; Okelsrud et al., 2016). Mercury contamination in waterways, sediments and fishes in SEA are already threatening frigate birds as well as other species in the area depending on marine resources, including humans (Mott et al., 2017). With an atmospheric residence time of up to two years (Schroeder and Munthe, 1998), Hg can be released from the atmosphere through both wet and dry deposition. $\mathrm{Hg}$ can subsequently be stored in lake and wetland sediments, thereby providing the basis for reconstructions of past variations in pollution loads (e.g. Bindler et al., 2001; Fitzgerald et al., 2005; Yang et al., 2010; Shotyk et al., 2017).

Little information on past levels of industry-derived air pollution in SEA is available, especially for the period pre-dating 1980 (US Energy Information; www.eia.gov). This is despite the growing concerns of the effects of local and regional pollution in SEA (Koplitz et al., 2016). This paper addresses this information gap in long-term variations in air pollution deposition in SEA and uses sedimentary evidence as a basis for reconstructing changes in atmospheric pollution in SEA covering the period from the start of industrial fuel consumption to the present, including the time interval before 1980 where data on atmospheric pollution levels are otherwise scarce.

\section{Materials and methods}

\section{$\underline{\text { Sites and sampling }}$}

Using logistical criteria such as site-accessibility and geographical spread, we selected sites from three countries in SEA in order to develop a regional reconstruction of atmospheric deposition pollution history: (1) sediment cores were obtained from three lakes in the Philippines (Yambo, Mohicap, Sampaloc) from the Seven Crater Lakes, a tight cluster of maar crater lakes located near San Pablo City, Laguna Province, on the island of Luzon (Fig. 1). The lakes are presumed to have formed through an explosive phreatic eruption from Mount Banahaw-San Cristobal (Brillo, 2016). The lakes are all moderately deep (>25 m water depth) and have surface areas ranging from 0.23 to 1.04 km² (Supplementary Table 1) (Aquino, 1983; Laguna Lake Development Authority, 2008). Lakes in the cluster are currently used for aquaculture across a range of intensities; those selected for this study range from relatively pristine (low level of aquaculture; Yambo) to heavily impacted (intensive aquaculture; Sampaloc). (2) Tasik Chini, a flood pulse wetland ecosystem in the state of Pahang, 
Peninsular Malaysia, consists of 12 shallow, interconnected lake basins (Shuhaimi-Othman et al., 2007). The lake is under strong ecological pressure due to a range of anthropogenic activities in the area, including deforestation for rubber and oil palm plantations, mining, and artificial damming of the lake (Sharip and Jusoh, 2010). (3) There are no natural freshwater ecosystems with long sediment records available for study in Singapore. Instead, we sampled a reservoir (SR) ${ }^{1}$, located in the largely forested Central Catchment of Singapore. Construction of SR began in 1970 with damming of the valley upstream of an existing reservoir (Public Utilities Board Website; http://www.pub.gov.sg).

Fieldwork was carried out in 2015 (Malaysia) and 2016 (the Philippines, Singapore). For each of our five selected sites we recovered a sediment core from the deepest part of the basin using a UWITEC gravity corer with an inner diameter of $86 \mathrm{~mm}$. As the recovered sediments were highly organic and unconsolidated, core penetration varied between $72-104 \mathrm{~cm}$. All cores preserved the sediment-water interface, and were subsampled in contiguous 1-cm-thick samples in the field.

\section{Radiometric dating}

Radiometric dates were obtained for the sediment cores from the Philippines and Malaysia by measuring ${ }^{210} \mathrm{~Pb},{ }^{226} \mathrm{Ra},{ }^{137} \mathrm{Cs}$ and ${ }^{241} \mathrm{Am}$ using gamma spectrometry; the SR record was not radiometrically dated, although the lowermost part of the sediment core recovered post-dates the onset of reservoir construction (1970). Radiometric dating used freeze-dried sediment samples analysed in ORTEC HPGe GWL series well-type coaxial low background intrinsic germanium detectors at University College London. ${ }^{210} \mathrm{~Pb}$ was determined via its gamma emissions at $46.5 \mathrm{keV}$, and ${ }^{226} \mathrm{Ra}$ by the $295 \mathrm{keV}$ and $352 \mathrm{keV}$ gamma rays emitted by its daughter isotope ${ }^{214} \mathrm{~Pb}$ following three weeks of storage in containers (sealed with rubber stops to prevent loss of ${ }^{222} \mathrm{Rn}$ (Pittauerova et al., 2011)) to allow radioactive equilibration (Appleby et al., 1986). ${ }^{137} \mathrm{Cs}$ and ${ }^{241} \mathrm{Am}$ were measured by their emissions at 662 and $59.5 \mathrm{keV}$ respectively (Appleby et al., 1986). A constant rate of supply (CRS) model was applied to each sediment core to create an age-depth model (Appleby, 2001). The CRS model assumes a constant rate of unsupported ${ }^{210} \mathrm{~Pb}$ supply to the sediment $\left({ }^{210} \mathrm{~Pb}\right.$ derived from atmospheric fallout is unsupported ${ }^{210} \mathrm{~Pb}$ ), and is one of the most widely used methods for calculating ages based on ${ }^{210} \mathrm{~Pb}$ activity (Appleby, 2001).

\section{$\underline{\text { SCP analysis }}$}

\footnotetext{
${ }^{1}$ The reservoir is anonymized in line with a request from the Public Utilities Board (Singapore) who kindly granted access to the site
} 
The SCP concentration of selected subsamples from all five study sites was determined following the protocol by Rose (1994). Dried sediment subsamples were digested with acids in order to remove organic, siliceous and carbonate sediment fractions. A known volume of processed subsample was then transferred to a coverslip and mounted on a glass microscope slide using Naphrax. SCPs were enumerated using a light microscope and expressed in concentration (number per gram of dry matter $\left.\left(\mathrm{gDM}^{-1}\right)\right)$. For the sites that were radiometrically dated, SCP concentrations were converted to flux $\left(\mathrm{n} \mathrm{cm}^{-2} \mathrm{yr}^{-1}\right)$ to take into account the variability in sediment accumulation rates (Rose et al., 1998). The detection limit for the technique is typically less than $100 \mathrm{gDM}^{-1}$ (Rose, 1994), and concentrations presented here have an accuracy of c. $\pm 30 \mathrm{gDM}^{-1}$ for Tasik Chini and c. $\pm 50-100 \mathrm{gDM}^{-1}$ for the other records. Rose (1994; 2008) provides more details on the SCP preparation protocol and criteria for identification.

\section{Mercury analysis}

We measured $\mathrm{Hg}$ concentrations in the sediment cores from Sampaloc and Yambo (Philippines) using cold vapour-atomic fluorescence spectrometry (CV-AFS). Samples were digested with $8 \mathrm{~mL}$ aqua regia at $100^{\circ} \mathrm{C}$ on a hotplate for $2 \mathrm{~h}$ in rigorously acid-leached $50 \mathrm{~mL}$ polypropylene digestion tubes, along with standard reference materials and sample blanks. The digested solutions (samples, standards and blanks) were subsequently analysed for Hg using CV-AFS following reduction with $\mathrm{SnCl}_{2}$ (Yang et al., 2016). The standard reference material used here (GBW07305; stream sediment) has a certified $\mathrm{Hg}$ value of $100 \pm 10 \mathrm{ng} \mathrm{g}^{-1}$; our measured mean value was $103.8 \mathrm{ng} \mathrm{g}^{-1}$, with a relative standard deviation (RSD) of $3.1 \mathrm{ng} \mathrm{g}^{-1}(\mathrm{n}=5)$.

\section{$\underline{\text { Regional climate and atmospheric modelling }}$}

The monsoonal climate of SEA results in large intra-annual variations in the extent of the air-shed (the area from which a parcel of air, and suspended pollutants, is likely to be sourced) for each of the study sites. This is because seasonal changes in the monsoonal system result in differences in wind direction (Fig. 1) as well as in marked differences in wet and dry periods in most of the region (Supplementary Table 2). Peninsular Malaysia and Singapore are affected by two major monsoon systems, the southwest monsoon (late May-September; Supplementary Table 2) and the northeast monsoon (November-March), which brings high amounts of precipitation. During the transitional months, the equatorial trough lies over Malaysia and winds are generally light and variable. In the Philippines, the summer southwest monsoon brings relatively high amounts of precipitation to most of the archipelago during May-October. The northeast winter monsoon is generally associated with lower quantities of precipitation (Supplementary Table 2). The Philippines are also bisected by a 
major tropical storm (typhoon) track, generally running east to west, with most major typhoons occurring between June and December (Kubota and Chan, 2009).

We analysed potential sources of atmospheric pollution for each of our sites by producing backward trajectories (72 h) of air masses for the Seven Crater Lake region (the Philippines), Tasik Chini (Peninsular Malaysia) and SR (Singapore) following Nagafuchi et al. (2009). The trajectories were plotted using the Hybrid Single-Particle Lagrangian Integrated Trajectory model (HYSPLIT) (Stein et al., 2015; Ready, http://www.ready.noaa.gov) using a weekly sampling resolution for five selected months (May 2016, August 2016, October 2016, November 2016, January 2017) that together represent the different modes of the monsoonal climate in SEA (Supplementary Table 2). The backward trajectory simulations started with air masses at $500 \mathrm{~m}$ above the modelled ground levels at starting point; trajectories were calculated based on meteorological data from the Global Data Assimilation System (NOAA, https://www.ready.noaa.gov/gdas1.php).

\section{Results}

\section{Radiometric dating}

The unsupported ${ }^{210} \mathrm{~Pb}$ profiles show non-monotonic features in the Mohicap, Sampaloc and Tasik Chini records (Supplementary Table 3), confirming the suitability of the CRS model over the alternative, Constant Initial Concentration (CIC) model (Robbins, 1978). Activities of ${ }^{137} \mathrm{Cs}$ and ${ }^{241} \mathrm{Am}$ in these three records are too low to validate ${ }^{210} \mathrm{~Pb}$-based evidence for dating. While the Yambo ${ }^{210} \mathrm{~Pb}$ profile shows a more regular pattern, small departures from an exponential decline also indicate the use of a CRS dating model for this core. A peak in ${ }^{137} \mathrm{Cs}$ activity at $39.5 \mathrm{~cm}$ depth in the Yambo record reflects the 1963 maximum in atmospheric ${ }^{137} \mathrm{Cs}$ fallout resulting from the testing of nuclear weapons. While ${ }^{137} \mathrm{Cs}$ can be mobile in natural environments, it is unlikely that the peak position would have changed. Therefore, the ${ }^{137} \mathrm{Cs}$ peak at $39.5 \mathrm{~cm}$ depth is used to correct the CRS ${ }^{210} \mathrm{~Pb}$ chronology, which initially placed 1963 at $28.5 \mathrm{~cm}$ depth. The offset in the ${ }^{210} \mathrm{~Pb}$ profile for the Yambo record might be the result of catchment-specific changes in sedimentation processes (such as changes in catchment erosion/inputs or sediment focussing) that might have changed the input of supported ${ }^{210} \mathrm{~Pb}$.

The resulting core chronologies (Fig. 2) suggest relatively high sedimentation rates at Mohicap, with an increase in rate of sedimentation between 1940 and 1970, followed by a uniform rate of $0.21 \mathrm{~g} \mathrm{~cm}^{-2} \mathrm{yr}^{-1}$. The Sampaloc record shows an increase in sedimentation rate around 1995, whereas the Yambo record shows relatively stable rates throughout. Rates of sedimentation are most variable in the Tasik Chini record, where step-wise increases can be seen around 1945 and 2000 , with considerable variations during the last decade. 


\section{SCP records}

Concentrations of SCPs in the three records from the Philippines and the record from Malaysia show similar trends, with first occurrences being observed in samples taken from the lower part of each core, followed by increasing concentrations in samples from higher in the sequence (Fig. 3). All records show decreasing concentrations in the uppermost part of the core. The concentrations differ from core to core, with maximum values reaching c. 40,000 SCPs gDM ${ }^{-1}$ at Sampaloc, but only c. 300 SCPs gDM-1 at Tasik Chini. The SR record shows continuous presence of SCPs from the onset of the core, with initial concentrations of SCPs of c. $800 \mathrm{SCPs} \mathrm{gDM}^{-1}$ around $70 \mathrm{~cm}$ core depth, subsequently increasing to maximum concentrations of c. $6000 \mathrm{SCPs} \mathrm{gDM}^{-1}$ at $45 \mathrm{~cm}$ core depth and with concentrations fluctuating between 2000-6000 SCPs gDM-1 in the upper part of the record.

First occurrences of SCPs often reflect early developments in the industrial combustion of coal and oil, and following two earlier samples with single occurrences of SCPs (Fig. 3) the Tasik Chini SCP flux record dates the onset of continuous presence of SCPs in sediment samples to c. 1950 (Fig. 4). The age-depth models of the cores from the Philippines do not reach back far enough to date first occurrences, and hence the SCP flux profiles are truncated. The Sampaloc record indicates that SCPS are encountered earlier than at Tasik Chini, with SCPs in the oldest sediment sample dated to $\mathrm{c}$. 1925. The four radiometrically dated records all show increased SCP fluxes around 1960, although fluxes at Tasik Chini are much lower $\left(10 \mathrm{~cm}^{-2} \mathrm{yr}^{-1}\right)$ than the values observed at the Philippine sites $\left(1000 \mathrm{~cm}^{-2} \mathrm{yr}^{-1}\right)$. Three of the four records show a second step-change increase in SCP flux around 1990, with all records showing maximum flux at around 2000. All four records subsequently show decreasing flux to the present.

\section{Mercury}

$278 \mathrm{Hg}$ concentrations range between 30 and $150 \mathrm{ng} \mathrm{g}^{-1}$ in the Sampaloc and Yambo records (Fig. 5). In the core from Sampaloc, maximum concentrations of $90-150 \mathrm{ng} \mathrm{g}^{-1}$ are reached between 30 and 55 $\mathrm{cm}$ depth. $\mathrm{Hg}$ concentrations were initially low in Yambo (30-40 $\mathrm{ng} \mathrm{g}^{-1}$ below $70 \mathrm{~cm}$ depth in the core), followed by relatively stable concentrations of $50-90 \mathrm{ng} \mathrm{g}^{-1}$ for the upper part of the record. When converted to flux, $\mathrm{Hg}$ in Sampaloc is around $40 \mu \mathrm{g} \mathrm{m}^{-2} \mathrm{yr}^{-1}$ for most of the sequence, with an increase to values over $80 \mathrm{\mu g} \mathrm{m}^{-2} \mathrm{yr}^{-1}$ between 1990 and 2005. The Yambo record initially shows a Hg flux of $60-90 \mu \mathrm{g} \mathrm{m}^{-2} \mathrm{yr}^{-1}$ prior to 1965 , after which it shows a relatively stable flux of c. $110 \mu \mathrm{g} \mathrm{m}^{-2} \mathrm{yr}^{-1}$. 
Atmospheric modelling (Fig. 1) indicates seasonal differences in the air masses reaching our study sites throughout the year. The winter monsoon (November-April; Supplementary Table 2) delivers air masses from mainly the east-northeast. While this means that air masses affecting the study sites in the Philippines mainly pass over the Philippine Sea, some of the backward trajectories suggest that southern Japan could also be a source of atmospheric pollution (e.g. Fig. 1c). As November-April is a period with relatively low precipitation in the Philippines, the chances for rain-out of atmospheric particles are lower, and airborne particles can potentially be transported further. In contrast, during June-September air masses over the Philippines arrive from the west, bringing relatively high amounts of precipitation. The modelling results suggest that there is only limited scope for airborne particle sources from outside of the Philippines to arrive at the study sites on the island of Luzon. Seasonal variability is slightly higher for the sites in Peninsular Malaysia and Singapore. Winds from the northeast dominate from October-January, southwestern winds from January-April, and southeasterly winds from May-September (Supplementary Table 2). Highest amounts of precipitation are commonly observed during the northeast monsoon (November-March) for eastern Peninsular Malaysia, suggesting that although the three-day trajectories cover large distances for these months, reaching as far as the South China Sea and the Indian Ocean (Fig 1c), airborne particles have a higher chance of raining out during this part of the year. The different directions of the air mass trajectories, in addition to the length of the three-day pathways, suggest that the sediment records of our sites represent a regionally integrated signal of air pollution, and that SCPs transported to our site could be partly derived from long-range transport (with travel distances potentially exceeding $10^{3} \mathrm{~km}$ ). However, the modelling results also suggest that for large parts of the year air masses mainly pass over open water, and combined with information on seasonality of precipitation, indicate that most of the airborne particles are probably derived from local sources.

\section{Discussion}

\section{Spatio-temporal trends of SCP fluxes}

Burning of fossil fuels in SEA started toward the end of the $19^{\text {th }}$ century albeit on a small scale. The first coal-fired power plant in the Philippines was built in Manila, also on the island of Luzon, in 1892 (Ongsotto and Ongsotto, 2002), and this and other power plants constructed in the vicinity of Manila could account for the early detection of SCPs in the record from Sampaloc (Fig. 4), located around $100 \mathrm{~km}$ to the south. Extensive and region-wide fossil fuel consumption did not begin until c. 19501960 , when all four ${ }^{210} \mathrm{~Pb}$-dated records show an increase in SCP flux. The use of fossil fuels was locally stimulated by legislation such as the Oil Exploration and Development Act (1972) of the 
Philippines, which offered tax exemptions for oil exploration and exploitation. The increase in coal and oil consumption after 1980 in SEA (Fig. 4b) is mirrored in the increase in SCP flux in the records of Yambo, Sampaloc and Tasik Chini, which all show a phase of SCP flux during the 1980s. A further increase in coal and oil consumption after 2000 (IEA, 2013; Kurokawa et al., 2013) is not reflected in the SCP records, which all show decreasing flux from that time. This divergence in trends might be the result of the implementation of air pollution control measures (Wang et al., 2014; Mohktar et al., 2014). For instance, an expansion of air pollution control measures in the Philippines followed implementation of the Philippines Clean Air Act of 1999 (Republic Act No. 8749), which set pollution emission limitations for the fossil fuel industry (as well as for motor vehicles). Implementation of air pollution control policies commenced in China from 1980 onward, but only became effective from c. 2005 onward (Yin et al., 2016). In Malaysia, the Malaysia Environmental Quality (Clean Air) of 1978 provided the first regulations relating to atmospheric pollution control, only recently being replaced regional differences in the timing of the introduction of air pollution control measures in Southeast and East Asia, their implementation was more strenuously enforced only from c. 2000 onward, and this is in line with our observed decrease in SCP fluxes in SEA.

Historical records of monthly precipitation amounts show a slight increase in rainfall in Malaysia from the 1990s onward (Climate Change Knowledge Portal, http://sdwebx.worldbank.org/climateportal), with the strongest increases in rainfall amounts seen during the northeast monsoon season (November-March). This increase in precipitation amounts could have resulted in more effective rain-out of particulates, and shortened transport distances for airborne particulates such as SCPs (e.g. Ruppel et al., 2013; Supplementary Figure 1). This would have decreased the amount of regionally-derived SCPs for some of our sites from c. 1990. It is however difficult to disentangle the potential effects of an increase in precipitation amounts from the effects of increasingly more effective air pollution control measures, as both would result in decreased SCP fluxes to our sites. More research is needed to differentiate between the effects of these two drivers of changes in SCP deposition at our sites.

Individual SCP flux records were standardised and combined in a regional summary record for SEA (Fig. 4c). The curve that is shown in Fig. 4c is dominated by the results from the Philippines, and is currently based on a relatively low number of records that are available for comparison. Future results from SEA might alter the general trend of the record shown in Fig. 4c. However, the current summary diagram resembles trends observed in extra-tropical parts of Asia, such as China and Japan. For instance, the record for Akani-konuma, a remote high-altitude lake in Japan, shows first occurrences of SCPs around the early 1950s, before reaching peak flux around the late-1980s 
(Nagafuchi et al., 2009). SCP concentration data from the middle Yangtze in China show an abrupt increase in the early 1950s, before declining from around 2000, while similar data from Beijing show a much more recent (late 1980s) increase, with the predominant morphology of SCPs indicating the combustion of coal as the main source (Wu et al., 2005; Hirakawa et al., 2011). By comparison, sediment cores from lakes Taihu and Donghu in eastern China both exhibit first occurrences of SCPs in the 1930s before showing rapid increases in SCP deposition around 1950 and peak flux at around 1990 (Rose, 2015). A similar pattern of accumulation is also shown in coastal sediments from Japan (Murakami-Kitase et al., 2010; Hirakawa et al., 2011). Sediment samples from the sub-aqueous part of the Yangtze Delta and dating to before the 1930s contain SCPs, with concentrations rising steeply in the early 1950s (Wang et al., 2014). The similar trends observed in our records and in the published records from Japan and China reflect the simultaneous expansion of fossil fuel combustion around this time. Rose (2015) provides a global synthesis of SCP records, illustrating that while certain parts of the world are well-studied (e.g. Europe), tropical regions are not, hampering our understanding of past atmospheric pollution patterns. Rose (2015) shows a normalised summary curve for Asia that includes 10 sites, but these sites cover a geographical range spanning from the northern Urals in Arctic Russia in the northwest (Solovieva et al., 2005) to Japan in the southeast (Yoshikawa et al., 2000; Nagafuchi et al., 2009), and all are located outside of tropical Asia. The summary curve for Asia (Rose, 2015) shows relatively low abundances or absence of SCPs pre-1950, followed by a trend of increasing flux from the mid-1950s to a peak around 1990. Inferred variations in atmospheric pollution levels for SEA are thus generally in line with information on fossil fuel usage in East and Southeast Asia (Ohara et al., 2007; Wang et al., 2014). While not outside of the range of dating uncertainties there are, however, slight differences in the SCP flux records from the two regions, with peak values being reached in East Asia at c. 1990 (Rose, 2015) but around 2000 in SEA (this study). In addition, the individual records from East Asia show decadal-scale differences when compared with each other as well. On a global scale, most SCP records show a more abrupt increase immediately after c. 1950, reaching peak flux values one or two decades earlier than the peak values as seen in our records. This likely reflects regional differences in development and pollution mitigation.

While future projections of black carbon emissions suggest globally decreasing concentrations, regional estimates differ between a slight increase (Streets et al., 2004) and a decrease (Wang et al., 2014) for SEA. The more recent estimates of a decrease in future emissions take into account substantial measures taken by local governments to reduce air pollution with the objectives of climate change mitigation as well as air quality improvement, such as the Environmental Quality (Clean Air) Regulation of 2014 in Malaysia (Mohktar et al., 2014; Wang et al., 
2014). Our results suggest that strict implementation of these regulations would lead to continued declines in SCP deposition. In contrast, the Philippine Energy Plan (PEP) 2012-2030 seeks to achieve energy independence through the use of indigenous fuel resources, including but not limited to indigenous coal and oil fields. This suggests that the Philippines will remain dependent on conventional fuels for the foreseeable future, thus affecting future SCP emissions in the region.

\section{Potential sources of SCPs}

While the patterns of variations in SCP loads are similar between the study sites, the absolute fluxes vary substantially. For instance, our records show that maximum flux at Tasik Chini only reaches 40 $\mathrm{cm}^{-2} \mathrm{yr}^{-1}$, whereas maximum flux in the Philippines reaches c. $2000 \mathrm{~cm}^{-2} \mathrm{yr}^{-1}$. SCP fluxes can vary over short distances (Rose and Appleby, 2005; Rose, 2015) and catchment- and site-specific processes like wind fetch, exposure, catchment slope, vegetation coverage and sediment transport all influence the extent to which SCPs accumulate in lake sediments, explaining some of the high spatial variability noted in other studies. However, proximity to pollution sources is the most likely explanation for the 2-order magnitude difference observed between our sites. Metropolitan Manila, the capital and by far the largest urban conurbation in the Philippines with an estimated population of 13 million, is located about $100 \mathrm{~km}$ to the north of the Seven Crater Lakes. San Pablo (population 266,000 ), which extends to the shoreline of Sampaloc, is also a relatively large, densely populated urban area. There are several power plants in the air-shed for the cluster of lakes forming the Seven Crater Lakes (Fig. 1b). While smaller-sized power generation facilities have been in operation from 1963 onward, large coal and oil plants came into operation in the 1980s and 1990s. These power plants can serve as local sources of SCPs accumulating in sediments at Mohicap, Sampaloc and Yambo. In contrast, all power plants on Peninsular Malaysia (Fig. 1a) are located on the western side of the peninsula. Tasik Chini therefore receives relatively more long-range emissions than the Philippine sites which receive more short-range transported SCPs.

\section{Mercury fluxes}

Global Hg emission rates have tripled since c. 1850, mainly due to increased coal burning (Engstrom et al., 2014; Horowitz et al., 2014). There are however many additional sources of anthropogenic $\mathrm{Hg}$ emission, including waste incineration and sulphide ore processing (Hylander and Meil, 2003). An important potential source of atmospheric $\mathrm{Hg}$ is artisanal and small-scale gold mining (Mason and Pirrone 2009, Cordy et al., 2010) and an estimated 300,000 people are employed in the small-scale mining sector of the Philippines (Lu, 2012). Artisanal mines have spread throughout the country since the mid-1980s gold-rush, with high numbers on the island of Mindanao to the south of Luzon 
423 (Appleton et al., 1999).The expanding practice of artisanal gold mining in SEA is responsible for much 424 of the region's environmental mercury emissions (Pacyna et al., 2010).

425 The first significant increases in $\mathrm{Hg}$ in lake sediment cores are typically observed from the mid-19 ${ }^{\text {th }}$ century, even in remote areas (Muir et al., 2009). While our records do not have age-depth models that reach back to the $19^{\text {th }}$ century, our record from Sampaloc shows an increase in $\mathrm{Hg}$ concentrations at c. $65 \mathrm{~cm}$ depth. We interpret this increase in concentration as a clear pollution signal, which occurred prior to c. 1925 (37 cm depth), the start of our chronology. The declining trend in $\mathrm{Hg}$ concentrations at Sampaloc is related to dilution as a result of increased sedimentation rates, as $\mathrm{Hg}$ flux increases from c. 1925 (Fig. 5). Similarly, Hg concentrations at Yambo increase from $85 \mathrm{~cm}$ onward, which is sometime before the c. 1950 (47 cm depth) onset of the sediment chronology for this site. The observed values of c. 40-110 $\mathrm{\mu g} \mathrm{m}^{-2} \mathrm{yr}^{-1}$ compare well to modern observations of wet deposition fluxes of total $\mathrm{Hg}$ in China, which ranges between 24.9 and $39.6 \mu \mathrm{g}$ $\mathrm{m}^{-2} \mathrm{yr}^{-1}$ for five study sites in the Wujiang River basin, but are much higher than observations of wet deposition fluxes for Europe and North America (Guo et al., 2008; Yang et al., 2009). However, comparison of fluxes derived from different types of observations as well as from different areas will be hampered by the difference in sources of input, as well as differences in the human impact on the landscape (e.g. deforestation). While the SCPs encountered in our records might reflect a local or regional source of pollution, the early increases in $\mathrm{Hg}$ concentrations most likely indicate a larger regional or even global impact, in line with observations elsewhere (Fitzgerald et al., 2005; Muir et al., 2009; Yang et al., 2010). The presence of artisanal gold mining as well as other small-scale mining activities will likely have provided additional local inputs of $\mathrm{Hg}$.

Impact of atmospheric pollution on Southeast Asian wetlands Lakes and wetland ecosystems are not equally vulnerable to pollution because of their differing ability to buffer the effects of pollutants, but little is known of the buffering capacity of aquatic ecosystems in SEA. Alkalinity of waters from Tasik Chini is rather low (0.05-0.20 meq L-1; unpubl. data), and thus poorly buffered and susceptible to acidification. The results of a region-wide precipitation monitoring project show that precipitation has an annual average $\mathrm{pH}$ of $<5.0$ for large parts of SEA, with sulphuric acid the main cause of acidification (EANET, 2011). Lake monitoring data

452 for sites in Malaysia and Indonesia provide evidence for declining lake-water pH and increasing 453 sulphate $\left(\mathrm{SO}_{4}{ }^{2-}\right)$ concentration, although the cause of apparent acidification remains unknown 454 (EANET, 2011; Sase et al., 2017). Combined with other pressures on water quality (e.g. sewerage 455 inputs from urban areas, fish farming, catchment disturbance, climate change), acidification poses a 
severe risk to aquatic ecosystem functioning and service provision in SEA, and indeed tropical Asia more widely.

SCP fluxes in SEA have declined over the last two decades (Fig. 4), likely as a result of the introduction of particle-arrestor technologies and improved pollution mitigation policies for industrial fuel combustion. In contrast, $\mathrm{Hg}$ fluxes at these lakes (Fig. 5) have remained relatively constant across the second half of the $20^{\text {th }}$ century to the present. Hg concentrations show a decreasing trend in Sampaloc, potentially related to dilution through increased sedimentation rates, and have remained stable at Yambo, despite the observed increase in sedimentation rates. While several pollution controls have constrained emissions of atmospheric $\mathrm{Hg}$ from e.g. power generation and cement production (Zhao et al., 2015), the more diverse sources of $\mathrm{Hg}$, including artisanal mining, might explain the absence of a decrease in sedimentary $\mathrm{Hg}$ concentrations in the Yambo record.

The increased sedimentation rates at Sampaloc and Yambo could partially reflect elevated levels of catchment soil erosion. This soil material includes $\mathrm{Hg}$ from atmospheric deposition over time, and is thus a source of delayed input of $\mathrm{Hg}$ (Yang et al., 2016). Hg flux to these lakes can therefore be expected to remain high for decades to come, even following the implementation of mitigation measures such as those associated with the Minamata Convention ( $\mathrm{Ha}$ et al., 2017). Transfer of Hg may therefore have potentially long-lasting impacts on aquatic and human health.

\section{Conclusions}

We used lake sediment archives to reconstruct trends in atmospheric pollution levels across SEA, covering the period from the start of industrial fuel consumption to the present. First occurrences of SCPs, reflecting early developments in the industrial combustion of coal and oil, are dated to c. 1950 at Tasik Chini (Malaysia) and are shown to predate c. 1925 at Sampaloc (Philippines). All SCP records show increasing fluxes from 1960 onward, indicating the onset of extensive and region-wide fossil fuel consumption. Increases in SCP fluxes between 1960 and 2000 reflect the increases in fossil fuel consumption in SEA, whereas the decreasing SCPs fluxes between 2000 and the present might be the result of the implementation of air pollution control measures. Atmospheric modelling suggests that most of the airborne particles are derived from local or regional sources. The trends observed in our SCP flux data compare well to independent records from extra-tropical parts of Asia, although peak flux is reached slightly later in SEA (around 2000) when compared to records from China and Japan (c. 1990).

The Sampaloc record shows an increase in $\mathrm{Hg}$ concentrations prior to c. 1925, the start of our chronology, which is interpreted as a clear pollution signal. Both the Sampaloc and the Yambo 
record show relatively high $\mathrm{Hg}$ fluxes with maximum fluxes reaching 90-110 $\mathrm{gg} \mathrm{m}^{-2} \mathrm{yr}^{-1}$. The reconstructed fluxes compare well to observations from China, but are higher than recent $\mathrm{Hg}$ deposition rates observed in Europe and North America. Whereas the SCPs encountered in our records might reflect a regional source of pollution, the early increases in $\mathrm{Hg}$ concentrations most likely indicate a larger regional or even global impact. The extensive presence of artisanal mining activities in the Philippines will likely have provided additional local inputs of $\mathrm{Hg}$.

\section{Acknowledgements}

Thanks are due to staff and students in the Research Center for the Natural and Applied Sciences, University of Santo Tomas, Manila, Philippines, for assistance in the field, and to the Public Utilities Board (PUB), Singapore, for permission to carry out fieldwork at UPR and also for assistance with fieldwork. Particular thanks are due to Rey Donna Papa and to Loh Sze Sian. We would also like to thank Virginia Panizzo and Wayne Bannister for logistic support, Keely Mills for advice during the design of the Tasik Chini research project, and Sarah Metcalfe for helpful comments on an earlier draft of the manuscript. Finally, we are grateful for the very constructive comments on an earlier version of this manuscript from three anonymous reviewers.

Supporting Information. Table S1 presents site information for the five study sites presented in this manuscript. Table S2 provides information on monthly wind (Table S2a) and precipitation (Table S2b) amounts for Singapore, Malaysia and the Philippines. Table S3 provides the ${ }^{210} \mathrm{~Pb}$ measurement data for the four radiometrically dated profiles. Figure S1 shows altitudes of air masses during the 72 hours prior to arriving at our sites for five selected dates (cf the data shown in Fig. 1c-11g)

\section{References}

Akimoto H (2003) Global air quality and pollution. Science 302, 1716-1719.

Amann M, Klimont Z, Wagner F (2013) Regional and Global Emissions of Air Pollutants: Recent Trends and Future Scenarios. Annu. Rev. Environ. Resour. 38, 31-55.

Appleby PG, Nolan PJ, Gifford DW, Godfrey MJ, Oldfield F, Anderson NJ, Battarbee RW (1986) ${ }^{210} \mathrm{~Pb}$ dating by low background gamma counting. Hydrobiologia 141, 21-27.

Appleby PG (2001) Chronostratigraphic techniques in recent sediments. In Tracking Environmental Change Using Lake Sediments. Vol. 1: Basin Analysis, Coring and Chronological Techniques; Last, W. M., Smol, J. P., Eds.; Kluwer: Dordrecht; pp 171-203. 
Appleton JD, Williams TM, Breward N, Apostol A, Miguel J, Miranda C (1999) Mercury contamination associated with artisanal gold mining on the island of Mindanao, the Philippines. Sci. Total Environ. 228, 95-105.

Aquino LV (1983) Using Spheroidal Carbonaceous Particles in lake sediments as a stratigraphic marker for the Anthropocene, Philippines. M.Sc. Dissertation, University of the Philippines, Iloilo City, Philippines.

Azimi S, Moghaddam MS (2013) Effect of mercury pollution on the urban environment and human health. Environ. Ecol. Res. 1, 12-20.

Barst BD, Ahad JME, Rose NL, Jautzy JJ, Drevnick PE, Gammon PR, Sanei H, Savard MM (2017) Lakesediment record of PAH, mercury, and fly-ash particle deposition near coal-fired power plants in Central Alberta. Environ. Pollut. 231, 644-653.

Bindler R, Renberg I, Appleby PG, Anderson NJ, Rose NL (2001) Mercury accumulation rates and spatial patterns in lake sediments from west Greenland: a coast to ice margin transect. Environ. Sci. Technol. 35, 1736-1741.

Brillo BBC (2016) Developing Mohicap Lake, San Pablo City, Philippines. Soc. Sci. 11, 283-290.

Chirinos L, Rose NL, Urrutia R, Muñoz P, Torrejón PF, Torres L, Cruces F, Araneda A, Zaror C (2006) Environmental evidence of fossil fuel pollution in Laguna Chica de San Pedro lake sediments (Central Chile). Environ. Pollut. 141, 247-256.

Cordy P, Veiga MM, Salih I, AI-Saadi S, Console S, Garcia O, Mesa LA, Velásquez-López PC, Roeser M (2011) Mercury contamination from artisanal gold mining in Antioquia, Colombia: The world's highest per capita mercury pollution. Sci. Total Environ. 410-411, 154-160.

EANET (2011) The second periodic report on the state of acid deposition in East Asia; Acid Deposition Monitoring Network in East Asia. Acid Deposition Monitoring Network in East Asia (EANET)

EANET (2015) Review on the State of Air Pollution in East Asia. Acid Deposition Monitoring Network in East Asia (EANET)

Engstrom DR, Fitzgerald WF, Cooke CA, Lamborg CH, Drevnick PE, Swain EB, Balogh SJ, Balcom PH (2014) Atmospheric Hg emissions from preindustrial gold and silver extraction in the Americas: A reevaluation from lake-sediment archives. Environ. Sci. Technol. 48, 6533-6543.

Fitzgerald WF, Engstrom DR, Lamborg CH, Tseng CM, Balcom PH, Hammerschmidt CR (2005) Modern and historic atmospheric mercury fluxes in northern Alaska: global sources and Arctic depletion. Environ. Sci. Technol. 39, 557-568.

Fu C, Ding A, Wu J (2017) Review on Studies of Air Pollution and Climate Change Interactions in Monsoon Asia. In: Chang C-P, Kuo H-C, Lau N-C, Johnson RH, Wheeler MC (Eds) The Global Monsoon System: Research and Forecast 9. pp 315-327. 
Guo Y, Feng X, Li Z, He T, Yan H, Meng B, Zhang J, Qiu G (2008) Distribution and wet deposition fluxes of total and methyl mercury in Wujiang River Basin, Guizhou, China. Atmosph. Environ. 42, 7096-7103.

Ha E, Basu N, Bose-O'Reilly S, Dorea JG, McSorley E, Sakamoto M, Chan HM (2017) Current progress on understanding the impact of mercury on human health. Environ. Res. 152, 419-433.

Hirakawa H, Muralami-Kitase A, Okudaira T, Inoue J, Yamazak H, Yoshikawa S (2011) The spatial and temporal distributions of spheroidal carbonaceous particles from sediment core samples from industrial cities in Japan and China. Environ. Earth Sci. 64, 833-840

Horowitz HM, Jacob DJ, Amos HM, Streets DG, Sunderland EM (2014) Historical Mercury Releases from Commercial Products: Global Environmental Implications. Environ. Sci. Technol. 48, 10242-10250.

Hylander LD, Meil IM (2003) 500 years of mercury production: global annual inventory by region until 2000 and associated emissions. Sci. Total Environ. 304, 13-27.

Inoue J, Momose A, Okudaira T, Murakami-Kitase A, Yamazaki H, Yoshikawa S (2014) Chemical compositions of Northeast Asian fly ash particles: Implications for their long-range transportation. Atmos. Environ. 95, 375-382.

Intergovernmental Panel on Climate Change (2014) Climate Change 2014: Synthesis Report. Contribution of Working Groups I, II and III to the Fifth Assessment Report of the Intergovernmental Panel on Climate. Geneva, Switzerland.

International Energy Agency (2013) Southeast Asia Energy Outlook. World Energy Outlook Special Report. Paris, France.

International Energy Agency (2016) Energy and air pollution. World Energy Outlook - Special report. Paris, France.

Jacobson MZ (2001) Strong radiative heating due to the mixing state of black carbon in atmospheric aerosols. Nature 409, 695- 697.

Kato $\mathrm{N}$, Akimoto $\mathrm{H}$ (1992) Anthropogenic emissions of $\mathrm{SO}_{2}$ and $\mathrm{NO}_{x}$ in Asia: emissions inventories, Atmos. Environ. 26, 2997-3017.

Klimont Z, Smith SJ, Cofala J (2013) The last decade of global anthropogenic sulfur dioxide: 2000-2011 emissions. Environ. Res. Lett. 8, 014003.

Kopf RK, Finlayson CM, Humphries P, Sims NC, Hladyz S (2015) Anthropocene baselines: assessing change and managing biodiversity in human-dominated aquatic ecosystem. Biosci 65, 798811.

Koplitz SN, Mickley LJ, Marlier ME, Buonocore JJ, Kim PS, Liu T, Sulprizio MP, DeFries R, Jacob DJ, Schwartz J, Pongsiri M, Myers S (2016) Public health impacts of the severe haze in Equatorial 
Asia in September-October 2015: demonstration of a new framework for informing fire management strategies to reduce downwind smoke exposure. Environ. Res. Lett. 11, 094023.

Koplitz SN, Jacobs DJ, Sulprizio MP, Myllyvirta L, Reid C (2017) Burden of Disease from Rising CoalFired Power Plant Emissions in Southeast Asia. Environ. Sci. Technol. 51, 1467-1476.

Kubota H, Chan JCL (2009) Interdecadal variability of tropical cyclone landfall in the Philippines from 1902 to 2005 . Geophys. Res Lett. 36, L12802.

Kurokawa J, Ohara T, Morikawa T, Hanayama S, Janssens-Maenhout G, Fukui T, Kawashima K, Akimoto H (2013) Emissions of air pollutants and greenhouse gases over Asian regions during 2000-2008: Regional Emission inventory in Asia (REAS) version 2. Atmos. Chem. Phys. 13, 11019-11058.

Laguna Lake Development Authority-Environmental Quality Management Division (2008) Water Quality Report of the Seven Crater Lakes 2006-2008. Rizal, Philippines.

Lai I-C, Lee C-L, Huang H-C (2016) A new conceptual model for quantifying transboundary contribution of atmospheric pollutants in the East Asia Pacific rim region. Environ. Internat. $88,160-168$.

Lau KM, Kim MK, Kim KM (2006) Asian summer monsoon anomalies induced by aerosol direct forcing: The role of the Tibetan Plateau. Clim. Dynam. 26, 855-864.

Lu JL (2012) Occupational health and safety in small scale mining: focus on women workers in the Philippines. J Internat. Women's Studies 13, 103-113.

Mason R, Pironne N (2009) Mercury Fate and Transport in the Global Atmosphere Emissions, Measurements and Models. Springer US, New York

Mohktar MM, Taib RM, Hassim MH (2014) Understanding selected trace elements behavior in a coal-fired power plant in Malaysia for assessment of abatement technologies. J Air \& Waste Manag. Assoc. 64, 867-878.

Mott R, Herrod A, Clarke RH (2017) Post-breeding dispersal of frigatebirds increases their exposure to mercury. Mar. Pollut. Bull. 119, 204-210.

Muir DCG, Wang X, Yang F, Nguyen N, Jackson TA, Evans MS, Douglas M, Kock G, Lamoureux S, Pienitz R, Smol JP, Vincent WF, Dastoor A (2009) Spatial trends and historical deposition of mercury in eastern and northern Canada inferred from lake sediment cores. Environ. Sci. Technol. 43, 4802-4809.

Murakami-Kitase A, Okudaira T, Inoue J, (2010) Relationship between surface morphology and chemical composition of spheroidal carbonaceous particles within sediment core samples recovered from Osaka Bay Japan. Environ. Earth Sci. 59, 1723-1729 
Nagafuchi O, Rose NL, Hoshika A, Satake K (2009) The temporal record and sources of atmospherically deposited fly-ash particles in Lake Akagi-konuma, a Japanese mountain lake. J. Paleolimnol. 42, 359-371.

Ohara T, Akimoto H, Kurokawa J, Horii N, Yamaji K, Yan X, Hayasaka T (2007) An Asian emission inventory of anthropogenic emission sources for the period 1980-2020. Atmosph. Chem. Phys. 7, 4419-4444.

Okelsrud A, Lydersen E, Fjeld E (2016) Biomagnification of mercury and selenium in two lakes in southern Norway. Sci. Total Environ. 566, 596-607.

Ongsotto RR, Ongsotto RR (2002) Philippine history module-based learning, $1^{\text {st }}$ ed; Rex Book Store: Manilla.

Pacyna EG, Pacyna JM, Sundseth K, Munthe J, Kindbom K, Wilson S, Steenhuisen F, Maxson P (2010) Global emission of mercury to the atmosphere from anthropogenic sources in 2005 and projections to 2020. Atmosph. Environ. 44, 2487-2499.

Pittauerová D, Hettwig B, Fischer HW (2011) Pb-210 sediment chronology: Focused on supported lead. Radioprotection 46, S277-S282.

Ramanathan V, Chung C, Kim D, Bettge T, Buja L, Kiehl JT, Washington WM, Fu Q, Sikka DR, Wild M (2005) Atmospheric brown clouds: impact on South Asian climate and hydrologic cycle. P. Natl. Acad. Sci. 102, 5326-5333.

Rice KM, Walker EM Jr, Wu M, Gillette C, Blough ER (2014) Environmental mercury and its toxic effects. J. Prev. Med. Public Health 47, 74-83.

Richter A, Burrows P, Nues H, Granier C, Niemeijer U (2005) Increase in tropospheric nitrogen dioxide over China observed from space. Nature 437, 129-130.

Robbins JA (1978) Geochemical and geophysical applications of radioactive lead. Biogeochem. Lead Environ. 1, 285-337.

Rose NL (1994) A note on further refinements to a procedure for the extraction of carbonaceous fly ash particles from sediments. J. Paleolimnol. 11, 201-204.

Rose NL (2001) Fly ash particles. In: Tracking Environmental Change Using Lake Sediments, Vol. 2. Physical and Chemical Techniques; Last, W. M., Smol, J. P., Eds.; Kluwer Academic Publishers: Dordrecht, pp. 319-349.

Rose NL (2008) Quality control in the analysis of lake sediments for spheroidal carbonaceous particles. Limnol. Oceanogr. Methods 6, 172-179.

Rose NL (2015) Spheroidal Carbonaceous Fly Ash Particles Provide a Globally Synchronous Stratigraphic Marker for the Anthropocene. Environ. Sci. Technol. 49, 4155-4162. 
Rose NL, Appleby PG (2005) Regional applications of lake sediment dating by spheroidal carbonaceous particle analysis I. United Kingdom. J. Paleolimnol. 34, 349-361.

Rose NL, Juggins S (1994) A spatial relationship between carbonaceous particles in lake sediments and sulphur deposition. Atmosph. Environ. 28, 177-183.

Rose NL, Juggins S, Watt J, Battarbee R (1994) Fuel-type characterisation of spheroidal carbonaceous particles using surface chemistry. Ambio. 23, 296-299.

Rose NL, Appleby PG, Boyle JF, Mackay AW, Flower RJ (1998) The spatial and temporal distribution of fossil-fuel derived pollutants in the sediment record of Lake Baikal, eastern Siberia. J. Paleolimnol. 20, 151-162.

Rose NL, Flower RJ, Appleby PG (2003) Spheroidal carbonaceous particles (SCPs) as indicators of atmospherically deposited pollutants in North African wetlands of conservation importance. Atmosph. Environ. 37, 1655-1663.

Rose NL, Jones VJ, Noon PE, Hodgson DA, Flower RJ, Appleby PG (2012) Long-range transport of pollutants to the Falkland Islands and Antarctica: Evidence from lake sediment fly-ash particle records. Environ. Sci. Technol. 46, 9881-9889.

Ruppel M, Lund MT, Grythe H, Rose NL, Weckström J, Korhola A (2013) Comparison of Spheroidal Carbonaceous Particle Data with Modelled Atmospheric Black Carbon Concentration and Deposition and Air Mass Sources in Northern Europe, 1850-2010. Adv. Meteorol. 2013, Article ID 393926, http://dx.doi.org/10.1155/2013/393926.

Sase H, Yamashita N, Luangjame J, Garivait H, Kietvuttinon B, Visaratana T, Kamisako M, Kobayashi R, Ohta S, Shindo J, Hayashi K, Toda H, Matsuda K (2017) Alkalinization and acidification of stream water with changes in atmospheric deposition in a tropical dry evergreen forest of northeastern Thailand. Hydrol. Proc. 31, 836-846.

Schroeder WH, Munthe J (1998) Atmospheric mercury - an overview. Atmosph. Environ. 32, 809822.

Sharip Z, Jusoh J (2010) Integrated lake basin management and its importance for Lake Chini and other lakes in Malaysia. Lakes Reservoirs: Res. Manag. 15, 41-51.

Sharip Z, Zaki ATA, Shapai MAHM, Suratman S, Shaaban AJ (2014) Lakes of Malaysia: Water quality, eutrophication and management. Lakes Reservoirs: Res. Manag. 19, 130-141.

Shotyk W, Appleby PG, Bicalho B, Davies LJ, Froese D, Grant-Weaver I, Magnan G, Mullan-Boudreau G, Noemberg T, Pelletier R, Shannon B, van Bellen S, Zaccone C (2017) Peat bogs document decades of declining atmospheric contamination by trace metals in the Athabasca Bituminous Sands Region. Environ. Sci. Technol. 51, 6237-6249. 
Shuhaimi-Othman M, Eng CL, Idris M (2007) Water Quality Changes in Chini Lake, Pahang, West Malaysia. Environ. Monit. Assess. 131, 279-292.

Solovieva N, Jones VJ, Nazarova L, Brooks SJ, Birks HJB, Grytnes J-A, Appleby PG, Kauppila T, Kondratenok BM, Renberg I, Ponomarev V (2005) Palaeolimnological evidence for recent climatic change in lakes from the northern Urals, arctic Russia. J. Paleolimnol. 33, 463-482.

Stein AF, Draxler RR, Rolph GD, Stunder BJB, Cohen MD, Ngan F (2015) NOAA's HYSPLIT atmospheric transport and dispersion modelling system. Bull. Amer. Meteor. Soc. 96, 2059-2077.

Stockholm International Water Institute (2009) Securing water for ecosystem and human well-being: the importance of environmental flows. Swedish Water House Report 24. Stockholm, Sweden.

Streets DG, Bond TC, Carmichael GR, Fernandes SD, Fu Q, He D, Klimont Z, Nelson SM, Tsai NY, Wang MQ, Woo J-H, Yarber KF (2003) An inventory of gaseous and primary aerosol emissions in Asia in the year 2000, J. Geophys. Res., 108, 8809.

Streets DG, Bond TC, Lee T, Jang C (2004) On the future of carbonaceous aerosol emissions. J. Geophys. Res. 109, D24212.

Wang SX, Zhao B, Cai SY, Klimont Z, Nielsen CP, Morikawa T, Woo JH, Kim Y, Fu X, Xu JY, Hao JM, He KB (2014) Emission trends and mitigation options for air pollutants in East Asia. Atmos. Chem. Phys. 14, 6571-6603.

Wang ZH, Dong YH, Chen J, Li XF, Cao J, Deng ZY (2014). Dating recent sediments from the subaqueous Yangtze Delta and adjacent continental shelf, China. J. Palaeogeog. 3, 207-218.

World Health Organisation Press (2016) World health statistics 2016. Monitoring for the Sustainable Development Goals. Geneva, Switzerland.

Wu YH, Wang SM, Xia WL, Liu J (2005) Dating recent lake sediments using spheroidal carbonaceous particle (SCP). Chin. Sci. Bull. 50, 1016-1020.

Yang H, Rose NL, Battarbee RW (2001) Dating of recent catchment peats using spheroidal carbonaceous particle (SCP) concentration profiles with particular reference to Lochnagar, Scotland. Holocene 11, 593-597.

Yang H, Berry A, Rose N, Berg T (2009) Decline in atmospheric mercury deposition in London. J. Environ. Monit. 11, 1518-1522.

Yang, H, Battarbee, RW, Turner, SD, Rose, NL, Derwent, RG, Wu, G, Yang R (2010). Historical reconstruction of mercury pollution across the Tibetan Plateau using lake sediments. Environ. Sci. Technol. 44, 2918-2924.

Yang H, Turner S, Rose NL (2016) Mercury pollution in the lake sediments and catchment soils of anthropogenically-disturbed sites across England. Environ. Pollut. 219, 1092-1101. 
Yin J, Andersson H, Zhang S (2016) Air Pollution Control Policies in China: A Retrospective and Prospects. Intern. J. Environ. Res. Publ. Health 13, 1219

Yoshikawa S, Yamaguchi S, Hata A (2000) Paleolimnological investigation of recent acidity changes in Sawanoike Pond, Kyoto, Japan. J. Paleolimnol. 23, 285-304.

Zhao Y, Zhong H, Zhang J, Nielsen CP (2015) Evaluating the effects of China's pollution controls on inter-annual trends and uncertainties of atmospheric mercury emissions. Atmos. Chem. Phys. 15, 4317-4337.

\section{Figures}

Fig. 1: a-b) Map of sites and locations of power plants. SCL = Seven Crater Lakes (Philippines); $\mathrm{TC}=$ Tasik Chini (Malaysia); SR = Singapore Reservoir (Singapore). Only power plants that started operations prior to 2000 are shown for the Philippines; c-g) 3-day isobaric backward trajectories ending at our study sites: Blue: air masses reaching the sites in the Philippines; green: air masses reaching Tasik Chini (Malaysia); red: air masses reaching Singapore. Orange arrows summarise seasonal wind directions based on the data shown in Supplementary Table 2, with panels showing characteristic months that exemplify the seasonal (monsoonal) variability in wind directions in SEA. Basemaps for (a) and (b) from www.freevectormaps.com

Fig. 2: Radiometric chronologies for the four dated records: Lake Mohicap, Lake Sampaloc, Lake Yambo (all Philippines) and Tasik Chini (Malaysia) showing the CRS model ${ }^{210} \mathrm{~Pb}$ dates and age (solid lines) as well as the sedimentation rates (dashed lines)

Fig. 3: SCP concentrations for Lake Mohicap, Sampaloc and Yambo (Philippines), Lake Tasik Chini (Malaysia) and a reservoir in Singapore (SR). Concentrations as number of particles per gram dry material $\left(\mathrm{n} \mathrm{gDM}^{-1}\right)$

Fig. 4: A. SCP fluxes for Lake Mohicap, Sampaloc and Yambo (Philippines) and Lake Tasik Chini (Malaysia) expressed as numbers of particles per $\mathrm{cm}^{2}$ per year $\left(\mathrm{n} \mathrm{cm}^{-2} \mathrm{yr}^{-1}\right)$. B. Coal ( $10^{3}$ short tonnes; ST) and oil ( $10^{3}$ barrels/day; bd $\left.^{-1}\right)$ usage in selected SEA countries since 1980 (www.eia.gov) C. Summary diagram for SEA with SCP sediment profile data from (a) normalized to the SCP accumulation peak (1.0) for the individual sites. Open circles reflect individual data points; the red line represents a general trend and is calculated by applying a LOESS smoother (span $=0.15$ ) to the data. Horizontal bar indicates $1950 \pm 5$ years representing the global increase in SCP contamination during the mid-20th century (Rose 2015) 
759 Fig. 5: SCP and Hg concentrations and fluxes for (a) Lake Sampaloc and (b) Lake Yambo (Philippines).

760 Concentration curves on a depth $(\mathrm{cm})$ scale; fluxes on an age scale with a secondary depth scale 761 plotted for comparison 

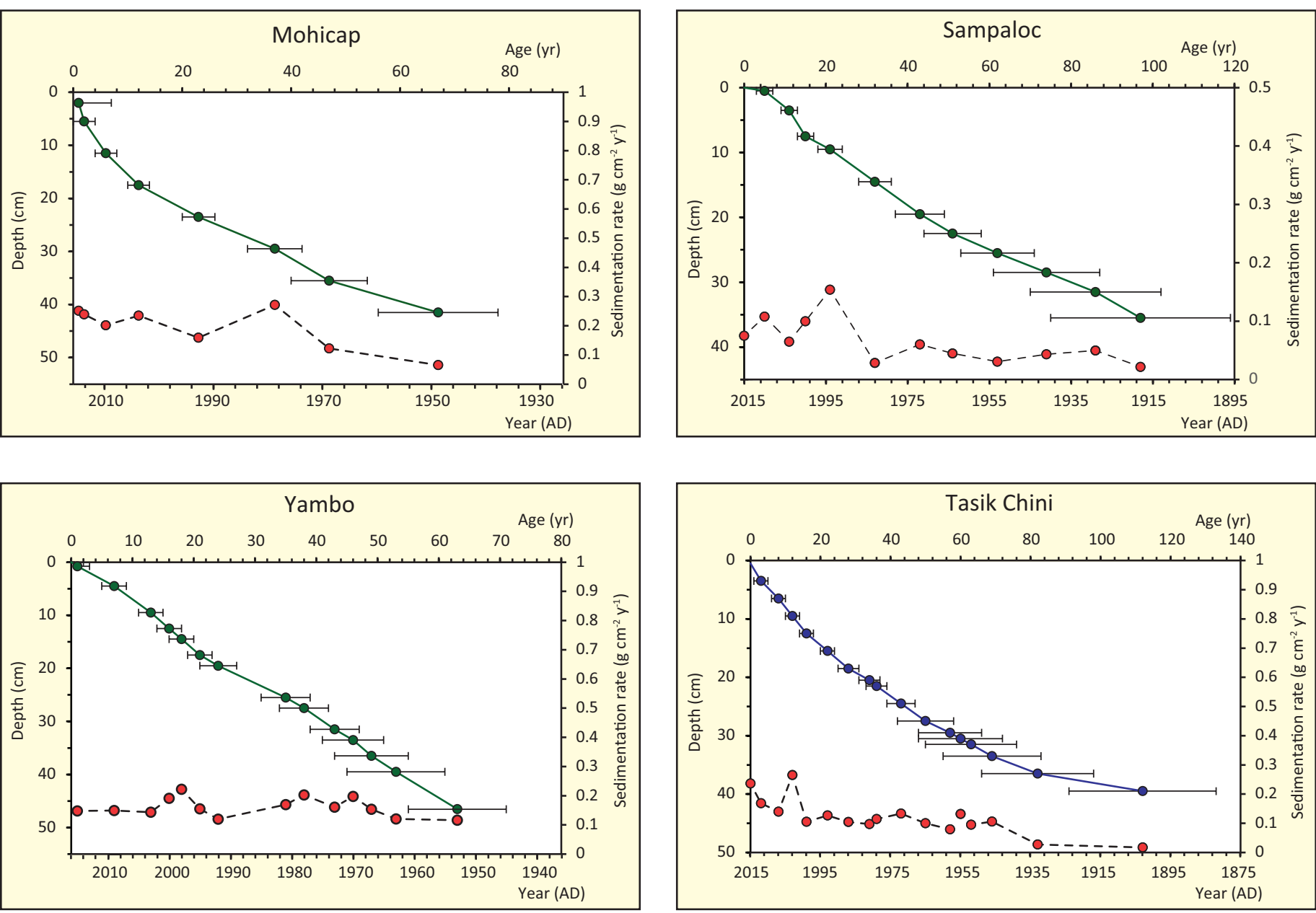

Fig. 2: Radiometric chronologies for the four dated record: Lake Mohicap, Lake Sampaloc, Lake Yambo (all Philippines) and Tasik Chini (Malaysia) showing the CRS model ${ }^{210} \mathrm{~Pb}$ dates and age (solid lines) as well as the sedimentation rates (dashed lines) 


$$
\text { IF=FF }
$$




\section{Supplementary information}

Table S1: Site information. Surface area is an approximation as this will seasonally vary for some of the sites. Water depths as recorded at time of coring.

\begin{tabular}{|c|c|c|c|c|c|c|c|}
\hline Site & Latitude (N) & Longitude (E) & $\begin{array}{l}\text { Altitude } \\
\text { (m) }\end{array}$ & $\begin{array}{l}\text { Surface } \\
\text { area } \\
\left(\mathrm{km}^{2}\right) \\
\end{array}$ & $\begin{array}{l}\text { Water } \\
\text { depth } \\
\text { (m) }\end{array}$ & Lake type & $\begin{array}{l}\text { Length } \\
\text { obtained } \\
\text { core }(\mathrm{cm})\end{array}$ \\
\hline \multicolumn{8}{|l|}{ Philippines } \\
\hline Mohicap & $14^{\circ} 07^{\prime} 19^{\prime \prime}$ & $121^{\circ} 20^{\prime} 03^{\prime \prime}$ & 99 & $0.23^{\mathrm{a})}$ & 30.4 & Crater lake & 87 \\
\hline Sampaloc & $14^{\circ} 04^{\prime} 44^{\prime \prime}$ & $121^{\circ} 19^{\prime} 47^{\prime \prime}$ & 108 & $1.04^{\mathrm{a})}$ & 27.6 & Crater lake & 81 \\
\hline Yambo & $14^{\circ} 07^{\prime} 09^{\prime \prime}$ & $121^{\circ} 21^{\prime} 59^{\prime \prime}$ & 207 & $0.30^{\mathrm{a})}$ & 38.0 & Crater lake & 104 \\
\hline \multicolumn{8}{|l|}{ Malaysia } \\
\hline Tasik Chini & $03^{\circ} 26^{\prime} 01^{\prime \prime}$ & $102^{\circ} 55^{\prime} 43.1^{\prime \prime}$ & 12 & $2.0^{\text {b) }}$ & 2.5 & $\begin{array}{l}\text { Floodpulse } \\
\text { wetland }\end{array}$ & 75 \\
\hline \multicolumn{8}{|l|}{ Singapore } \\
\hline Reservoir & $01^{\circ} 22^{\prime} 13^{\prime \prime}$ & $103^{\circ} 48^{\prime} 11^{\prime \prime}$ & 42 & $3.2^{c)}$ & 7.8 & Reservoir & 72 \\
\hline
\end{tabular}

a) Brillo BBC (2016) Developing Mohicap Lake, San Pablo City, Philippines. Soc. Sci. 11, 283-290.

b) Shuhaimi-Othman M, Eng CL, Idris M (2007) Water Quality Changes in Chini Lake, Pahang, West Malaysia. Environ. Monit. Assess. 131, 279-292.

c) Public Utilities Board Website; http://www.pub.gov.sg/abcwatersIM/upper-peirce.html

Table S2: Monthly measurements of wind directions and precipitation amounts for each of our study areas. Color codes in table $2 \mathrm{a}$ indicate time intervals with similar wind conditions. Black boxes indicate months selected for backward trajectory modelling

Table S2a. Monthly wind patterns

\begin{tabular}{|c|c|c|c|c|c|c|c|c|c|c|c|c|}
\hline & Jan & Feb & Mar & $\mathrm{Apr}$ & May & Jun & Jul & Aug & Sep & Oct & Nov & Dec \\
\hline Philippines & ESE & ESE & ESE & ESE & $\begin{array}{l}\text { WSW- } \\
\text { ESE }\end{array}$ & $\begin{array}{l}\text { WSW- } \\
\text { ESE }\end{array}$ & $\begin{array}{l}\text { WSW- } \\
\text { ESE }\end{array}$ & WSW & WSW & $\begin{array}{l}\text { WSW- } \\
\text { ESE }\end{array}$ & ESE & ESE \\
\hline Malaysia & SW-NE & SW-NE & SW-NE & SW-NE & SSE & SSE & SSE & SSE & SSE & $\begin{array}{l}\text { WNW- } \\
\text { SSW }\end{array}$ & $\begin{array}{l}\text { WNW- } \\
\text { NNE }\end{array}$ & $\begin{array}{l}\text { NW- } \\
\text { NE }\end{array}$ \\
\hline Singapore & $\mathrm{NE}$ & $\mathrm{NE}$ & $\mathrm{NE}$ & $\mathrm{NE}$ & SSW & SSW & SSW & SSW & SSW & SSW & $\mathrm{NE}$ & $\mathrm{NE}$ \\
\hline
\end{tabular}

Wind directions retrieved from the freely available data on:

https://www.windfinder.com/windstatistics/manila_airport

https://www.windfinder.com/windstatistics/morib_kuala_lumpur

https://www.windfinder.com/windstatistics/singapore_changi

Table S2b. Monthly precipitation (mm)

\begin{tabular}{|c|c|c|c|c|c|c|c|c|c|c|c|c|}
\hline & Jan & Feb & mar & Apr & May & Jun & Jul & Aug & Sep & Oct & Nov & Dec \\
\hline Philippines & 5 & 34 & 10 & 23 & 126 & 101 & 274 & 648 & 96 & 251 & 44 & 66 \\
\hline Malaysia & 115 & 110 & 154 & 254 & 427 & 235 & 315 & 149 & 174 & 169 & 629 & 290 \\
\hline Singapore & 293 & 231 & 177 & 260 & 174 & 115 & 137 & 123 & 124 & 228 & 378 & 409 \\
\hline
\end{tabular}

Philippines: measurements for Manila, year: 2016; data from www.worldweatheronline.com

Malaysia: measurements for Kuala Lumpur, year: 2016; data from www.worldweatheronline.com

Singapore: measurements for Singapore City, year: 2016; data from www.worldweatheronline.com 
Table S3a. ${ }^{210} \mathrm{~Pb}$ and ${ }^{137} \mathrm{Cs}$ concentrations in core $\mathrm{MOH}$ taken from Mohicap, Philippines.

\begin{tabular}{|c|c|c|c|c|c|c|c|c|c|}
\hline \multirow{3}{*}{$\begin{array}{l}\text { Depth } \\
\text { cm }\end{array}$} & \multirow{3}{*}{$\begin{array}{l}\text { Dry Mass } \\
\mathrm{g} \mathrm{cm}^{-2}\end{array}$} & \multicolumn{6}{|c|}{$\mathrm{Pb}-210$} & \multirow{3}{*}{$\begin{array}{l}\mathrm{Cs}-137 \\
\mathrm{~Bq} \mathrm{Kg}^{-1}\end{array}$} & \multirow[b]{3}{*}{ \pm} \\
\hline & & \multicolumn{2}{|c|}{ Total } & \multicolumn{2}{|c|}{ Supported } & \multicolumn{2}{|c|}{ Unsupp } & & \\
\hline & & $\mathrm{Bq} \mathrm{Kg}^{-1}$ & \pm & $\mathrm{Bq} \mathrm{Kg}{ }^{-1}$ & \pm & $\mathrm{Bq} \mathrm{Kg}{ }^{-1}$ & \pm & & \\
\hline 2.0 & 0.1907 & 186.45 & 25.77 & 41.13 & 7.19 & 145.32 & 26.75 & 0 & 0 \\
\hline 5.5 & 0.5337 & 175.01 & 20.89 & 28.81 & 5.66 & 146.20 & 21.64 & 0 & 0 \\
\hline 11.5 & 1.3437 & 191.27 & 21.59 & 36.55 & 6.01 & 154.72 & 22.41 & 0 & 0 \\
\hline 17.5 & 2.6547 & 147.99 & 16.05 & 37.85 & 4.40 & 110.17 & 16.64 & 0 & 0 \\
\hline 23.5 & 4.8498 & 130.70 & 15.00 & 16.56 & 3.75 & 114.14 & 15.46 & 0 & 0 \\
\hline 29.5 & 7.6704 & 75.04 & 7.55 & 31.72 & 2.04 & 43.32 & 7.82 & 0 & 0 \\
\hline 35.5 & 9.5238 & 98.93 & 13.53 & 29.01 & 3.68 & 69.92 & 14.02 & 3.31 & 1.68 \\
\hline 41.5 & 11.2548 & 101.49 & 10.56 & 29.24 & 2.69 & 72.25 & 10.90 & 0 & 0 \\
\hline 47.5 & 15.9975 & 33.67 & 11.68 & 38.63 & 3.69 & -4.96 & 12.25 & 0 & 0 \\
\hline 54.5 & 23.5701 & 59.87 & 18.72 & 36.92 & 2.46 & -7.05 & 18.88 & 0 & 0 \\
\hline 61.5 & 29.5457 & 42.00 & 23.36 & 52.03 & 6.03 & -10.03 & 24.13 & 0 & 0 \\
\hline
\end{tabular}

Table S3b. ${ }^{210} \mathrm{~Pb}$ and ${ }^{137} \mathrm{Cs}$ concentrations in core SAMP taken from Sampaloc, Philippines.

\begin{tabular}{|c|c|c|c|c|c|c|c|c|c|}
\hline \multirow{3}{*}{$\begin{array}{l}\text { Depth } \\
\mathrm{cm}\end{array}$} & \multirow{3}{*}{$\begin{array}{l}\text { Dry Mass } \\
\mathrm{g} \mathrm{cm}^{-2}\end{array}$} & \multicolumn{6}{|l|}{$\mathrm{Pb}-210$} & \multicolumn{2}{|l|}{ Cs-137 } \\
\hline & & \multicolumn{2}{|l|}{ Total } & \multicolumn{2}{|c|}{ Supported } & \multicolumn{2}{|l|}{ Unsupp } & \multirow[b]{2}{*}{$\mathrm{Bq} \mathrm{Kg}^{-1}$} & \multirow[b]{2}{*}{ \pm} \\
\hline & & $\mathrm{Bq} \mathrm{Kg}^{-1}$ & \pm & $\mathrm{Bq} \mathrm{Kg}^{-1}$ & \pm & $\mathrm{Bq} \mathrm{Kg}^{-1}$ & \pm & & \\
\hline 0.5 & 0.031 & 189.61 & 18.76 & 25.84 & 3.89 & 163.77 & 19.16 & 0 & 0 \\
\hline 3.5 & 0.4713 & 125.17 & 14.04 & 27.33 & 3.37 & 97.84 & 14.44 & 0 & 0 \\
\hline 7.5 & 0.9571 & 161.75 & 13.73 & 26.41 & 3.24 & 135.34 & 14.11 & 0 & 0 \\
\hline 9.5 & 1.2822 & 118.42 & 26.54 & 40.84 & 6.16 & 77.58 & 27.25 & 0 & 0 \\
\hline 14.5 & 1.991 & 85.44 & 13.66 & 43.36 & 3.02 & 42.08 & 13.99 & 0 & 0 \\
\hline 19.5 & 2.6652 & 212.88 & 33.03 & 51.12 & 7.85 & 161.76 & 33.95 & 0 & 0 \\
\hline 22.5 & 3.0848 & 86.63 & 13.83 & 31.69 & 3.62 & 54.94 & 14.3 & 0 & 0 \\
\hline 25.5 & 3.5043 & 112.18 & 25.03 & 54.37 & 6.42 & 57.81 & 25.84 & 0 & 0 \\
\hline 28.5 & 3.9305 & 92.49 & 13.38 & 33.4 & 4.36 & 59.09 & 14.07 & 0 & 0 \\
\hline 31.5 & 4.3566 & 66.32 & 13.75 & 37.64 & 4.63 & 28.68 & 14.51 & 0 & 0 \\
\hline 35.5 & 4.9398 & 41.12 & 9.37 & 31.3 & 3.21 & 9.82 & 9.9 & 0 & 0 \\
\hline 39.5 & 5.523 & 61.48 & 9.88 & 33.56 & 3.21 & 27.92 & 10.39 & 0 & 0 \\
\hline 42.5 & 6.0576 & 55.44 & 7.79 & 30.8 & 2.47 & 24.64 & 8.17 & 0 & 0 \\
\hline 46.5 & 6.7704 & 38.22 & 9.15 & 46.47 & 2.47 & -8.25 & 9.48 & 0 & 0 \\
\hline 54.5 & 8.4348 & 38.22 & 9.86 & 38.83 & 2.48 & -0.61 & 10.17 & 0 & 0 \\
\hline 69.5 & 11.7134 & 25.03 & 7.75 & 31.78 & 2.32 & -6.75 & 8.09 & 0 & 0 \\
\hline
\end{tabular}

Table S3c. ${ }^{210} \mathrm{~Pb}$ and ${ }^{137} \mathrm{Cs}$ concentrations in core YAMB taken from Yambo, Philippines.

\begin{tabular}{rrrrrrrrrr}
\hline Depth & Dry Mass & \multicolumn{9}{c}{ Total } & \multicolumn{4}{c}{ Pb-210 } & \multicolumn{5}{c}{ Supported } & \multicolumn{2}{c}{ Unsupp } \\
\multicolumn{1}{c}{ cm } & \multicolumn{1}{c}{$\mathrm{g} \mathrm{cm}^{-2}$} & \multicolumn{1}{c}{$\mathrm{Bq} \mathrm{Kg}^{-1}$} & \multicolumn{1}{c}{ \pm} & \multicolumn{1}{c}{$\mathrm{Bq} \mathrm{Kg}^{-1}$} & \multicolumn{1}{c}{ \pm} & \multicolumn{1}{c}{$\mathrm{Bq} \mathrm{Kg}^{-1}$} & \multicolumn{1}{c}{ \pm} & $\mathrm{Bq} \mathrm{Kg}^{-1}$ & \multicolumn{1}{c}{ \pm} \\
\hline 0.75 & 0.1188 & 210.23 & 17.38 & 44.97 & 4.19 & 165.26 & 17.88 & 0 & 0 \\
4.5 & 1.0329 & 173.6 & 13.81 & 38.15 & 3.17 & 135.45 & 14.17 & 4.29 & 1.33 \\
9.5 & 1.9378 & 159.12 & 18.7 & 43.17 & 4.14 & 115.95 & 19.15 & 0 & 0 \\
12.5 & 2.446 & 115.47 & 12.66 & 36.25 & 3.18 & 79.22 & 13.05 & 0 & 0 \\
14.5 & 2.7848 & 102.58 & 12.45 & 37.75 & 3.39 & 64.83 & 12.9 & 0 & 0 \\
17.5 & 3.341 & 112.62 & 13 & 28.15 & 2.98 & 84.47 & 13.34 & 0 & 0 \\
19.5 & 3.7118 & 149.55 & 13.55 & 48.8 & 3.7 & 100.75 & 14.05 & 0 & 0 \\
25.5 & 5.2979 & 94.3 & 8.33 & 44.43 & 2.13 & 49.87 & 8.6 & 5.21 & 0.79 \\
27.5 & 5.8124 & 73.8 & 10.19 & 35.54 & 2.75 & 38.26 & 10.55 & 0 & 0 \\
31.5 & 6.8414 & 78.78 & 11.31 & 38.36 & 3.21 & 40.42 & 11.76 & 6.43 & 1.47 \\
33.5 & 7.2229 & 62.26 & 6.77 & 31.53 & 1.78 & 30.73 & 7 & 6.34 & 0.85
\end{tabular}




\begin{tabular}{rrrrrrrrrr}
36.5 & 7.7952 & 81 & 11.4 & 45.26 & 2.99 & 35.74 & 11.79 & 6.12 & 1.4 \\
39.5 & 8.3674 & 81.38 & 8.27 & 41.49 & 2.18 & 39.89 & 8.55 & 15.94 & 1.23 \\
46.5 & 9.507 & 69.45 & 10.09 & 38.75 & 2.81 & 30.7 & 10.47 & 0 & 0 \\
54.5 & 10.787 & 27.21 & 6.82 & 39.71 & 2.03 & -12.5 & 7.12 & 1.53 & 0.82 \\
61.5 & 12.0589 & 42.3 & 8.39 & 43.69 & 2.97 & -1.39 & 8.9 & 2.86 & 1.37 \\
69.5 & 13.3613 & 48.04 & 7.33 & 36.11 & 2.57 & 11.93 & 7.77 & 0 & 0 \\
79.5 & 16.7343 & 27.91 & 4.81 & 34.25 & 1.59 & -6.34 & 5.07 & 0 & 0 \\
\hline
\end{tabular}

Table S3d. ${ }^{210} \mathrm{~Pb}$ and ${ }^{137} \mathrm{Cs}$ concentrations in core TC-1a taken from Tasik Chini, Malaysia

\begin{tabular}{|c|c|c|c|c|c|c|c|c|c|}
\hline \multirow{3}{*}{$\begin{array}{l}\text { Depth } \\
\mathrm{cm}\end{array}$} & \multirow{3}{*}{$\begin{array}{l}\text { Dry Mass } \\
\mathrm{g} \mathrm{cm}^{-2}\end{array}$} & \multicolumn{6}{|l|}{$\mathrm{Pb}-210$} & \multicolumn{2}{|l|}{ Cs-137 } \\
\hline & & \multicolumn{2}{|l|}{ Total } & \multicolumn{2}{|c|}{ Supported } & \multicolumn{2}{|l|}{ Unsupp } & \multirow[b]{2}{*}{$\mathrm{Bq} \mathrm{Kg}^{-1}$} & \multirow[b]{2}{*}{ \pm} \\
\hline & & $\mathrm{Bq} \mathrm{Kg}^{-1}$ & \pm & $\mathrm{Bq} \mathrm{Kg}^{-1}$ & \pm & $\mathrm{Bq} \mathrm{Kg}^{-1}$ & \pm & & \\
\hline 0.5 & 0.0629 & 222.37 & 18.68 & 99.3 & 6.6 & 123.07 & 19.81 & 0 & 0 \\
\hline 3.5 & 0.5566 & 261.24 & 25.25 & 101.91 & 6.87 & 159.33 & 26.17 & 0 & 0 \\
\hline 6.5 & 1.3096 & 258.91 & 15.12 & 93.59 & 4.21 & 165.32 & 15.7 & 0 & 0 \\
\hline 9.5 & 2.0703 & 180.6 & 12.69 & 103.94 & 4.13 & 76.66 & 13.35 & 0 & 0 \\
\hline 12.5 & 2.831 & 289.54 & 17.23 & 121.56 & 5.16 & 167.98 & 17.99 & 0 & 0 \\
\hline 15.5 & 3.4948 & 243.46 & 14.61 & 127.83 & 4.59 & 115.63 & 15.31 & 0 & 0 \\
\hline 18.5 & 4.1993 & 246.71 & 8.2 & 130.11 & 2.51 & 116.6 & 8.58 & 1.70 & 0.93 \\
\hline 20.5 & 4.727 & 231.31 & 14.74 & 125.17 & 4.66 & 106.14 & 15.46 & 0 & 0 \\
\hline 21.5 & 4.9952 & 222.06 & 13.18 & 138.56 & 4.66 & 83.5 & 13.98 & 3.21 & 1.61 \\
\hline 24.5 & 5.8104 & 207.79 & 14.69 & 149.46 & 4.85 & 58.33 & 15.47 & 0 & 0 \\
\hline 27.5 & 6.6602 & 208.11 & 14.27 & 146.57 & 4.81 & 61.54 & 15.06 & 0 & 0 \\
\hline 29.5 & 7.242 & 193.97 & 12.92 & 130.19 & 4.32 & 63.78 & 13.62 & 0 & 0 \\
\hline 30.5 & 7.5406 & 168 & 8.22 & 133.3 & 2.64 & 34.7 & 8.63 & 0 & 0 \\
\hline 31.5 & 7.867 & 175.94 & 12.34 & 131.88 & 4.09 & 44.06 & 13 & 0 & 0 \\
\hline 33.5 & 8.47 & 163.96 & 12.98 & 131.15 & 4.36 & 32.81 & 13.69 & 0 & 0 \\
\hline 36.5 & 9.1938 & 229.49 & 18.23 & 147.58 & 5.82 & 81.91 & 19.14 & 0 & 0 \\
\hline 39.5 & 9.8468 & 204.35 & 10.35 & 151.23 & 3.57 & 53.12 & 10.95 & 0 & 0 \\
\hline 42.5 & 10.4958 & 169.54 & 13.99 & 147.42 & 4.96 & 22.12 & 14.84 & 0 & 0 \\
\hline 45.5 & 11.174 & 139.73 & 12.95 & 143.78 & 4.8 & -4.05 & 13.81 & 0 & 0 \\
\hline 48.5 & 11.8296 & 147.14 & 16.61 & 143.79 & 4.74 & 3.35 & 17.27 & 0 & 0 \\
\hline
\end{tabular}


Figure S1a: Typical plot of variations over time in altitude of air parcels arriving at three study sites: January $1^{\text {st }} 2017$



Figure S1b: Typical plot of variations over time in altitude of air parcels arriving at three study sites: May $1^{\text {st }} 2016$



Figure S1c: Typical plot of variations over time in altitude of air parcels arriving at three study sites: August $1^{\text {st }} 2016$ 




Figure S1d: Typical plot of variations over time in altitude of air parcels arriving at three study sites: October $1^{\text {st }} 2016$

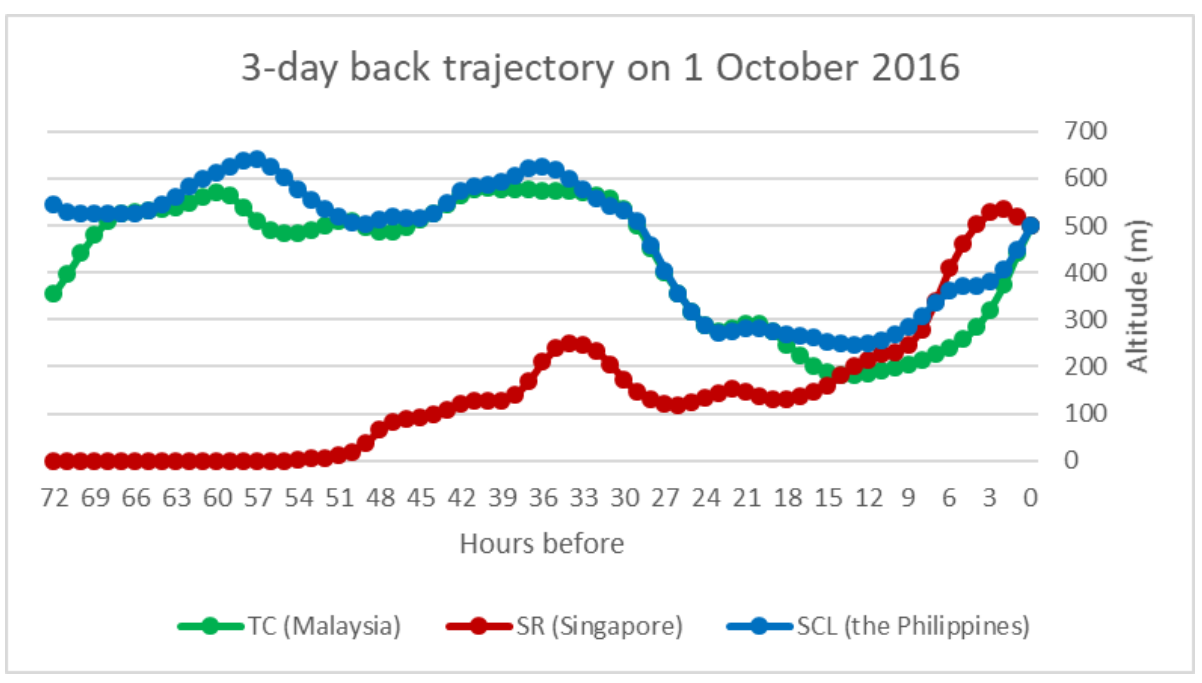

Figure S1e: Typical plot of variations over time in altitude of air parcels arriving at three study sites: November $1^{\text {st }} 2016$

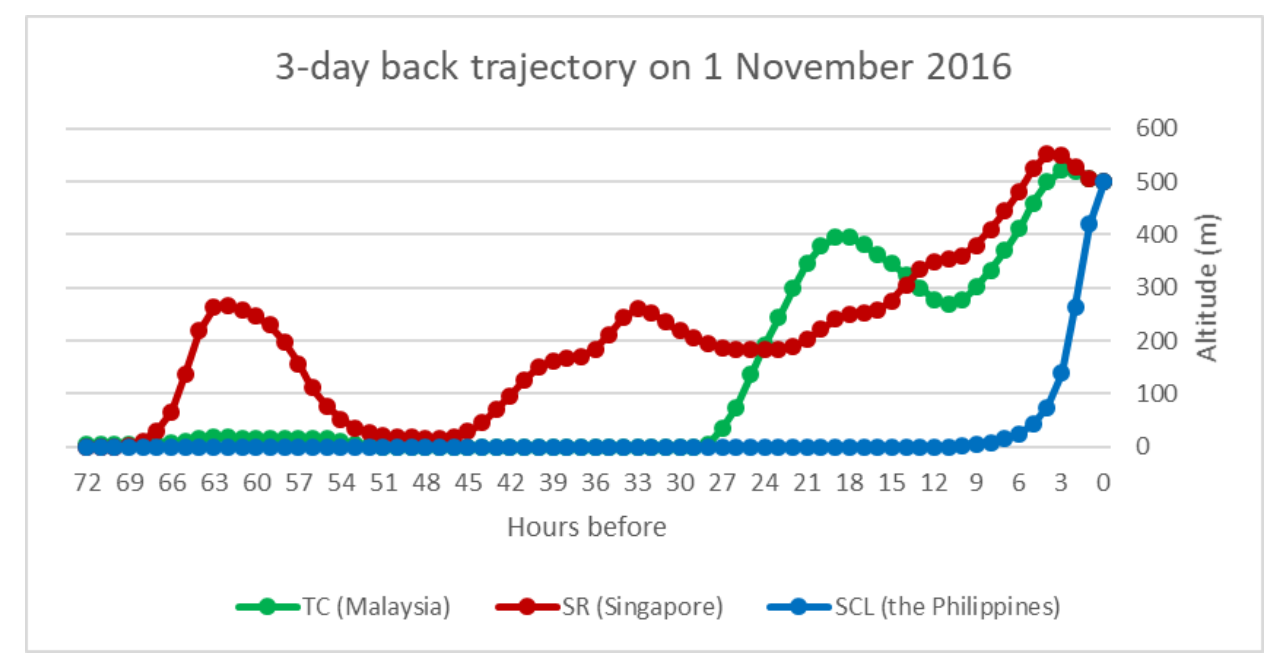


